\title{
'The Surprise of a Large Town': Regional Landscape in Alan Plater's Land of Green Ginger
}

\author{
Dave Rolinson
}

This article uses Land of Green Ginger (1973) as a case study of the engagement with regional place which occurred within television drama from BBC Birmingham during the 1970s and early 1980s. Filmed on location in Hull, the play was transmitted in the networked BBC1 strand Play for Today (1970-84). This article begins by locating the play within the context of BBC Birmingham as an institutional framework which produced dramas with common themes and approaches, before considering how regional identity is reinforced by the play's aesthetics. In addition to close textual analysis, this study draws from unpublished sources including the pre-production script, BBC records and a new interview with its scriptwriter, Alan Plater.

\section{English Regions Drama}

The stylistic and thematic approaches of Land of Green Ginger are characteristic of the drama produced by David Rose at BBC Birmingham. Plater (2003: 204) has traced his own development within a 'Golden Age' of television drama in which the autonomy of producers and high numbers of play commissions provided writers with apprenticeships. He argued that 'a playwright cannot exist without a patron', but patronage, in this sense, has aesthetic connotations, given that BBC Birmingham was predicated upon creating 'regional' drama. ${ }^{1}$

The foundation of English Regions provision at BBC Birmingham emerged from complaints over television's apparent London bias (echoing current plans to relocate BBC departments from London to Manchester). Emerging from its consultation paper 'Broadcasting in the 1970s', the BBC announced a 'devolution of editorial power' to Birmingham (Hanson 2000: 58), with Rose employed as Head of English Regions Drama in April 1971. Patrick Campbell (1972: 10) traced the 'quiet revolution' of Rose and his remit to 'cast his net over 


\section{Dave Rolinson}

all of non-metropolitan England', but a full-length study of Rose's career - from producer of ground-breaking early Z Cars (1962-78) to Commissioning Editor for Film on Four in the 1980s - remains overdue. However, a brief summary of his industrial position usefully contextualises the specific depiction of place in Land of Green Ginger.

Just as television drama in general drew vitally from radical theatre, so English Regions Drama, in particular, drew from regional repertory theatre. ${ }^{2}$ Rose recruited Barry Hanson from theatre in Hull as Script Editor and was keen, as he told Campbell, 'to pursue the association with regional theatre'. Plater's Trinity Tales (1975) is a fine example of this 'association': a variation on Geoffrey Chaucer's Canterbury Tales with six plays following rugby league supporters to Wembley for the Cup final, which Rose described as 'something new in concept' (Anonymous 1975: 14). A television version was written first, then, while rehearsals took place, a theatre version was written and performed with the same cast at Birmingham Rep. Comparable collaborations include The Writing on the Wall (1975) with Hull Truck, and The Permissive Society (1975) with Mike Leigh. Regional work found national slots including BBC1's Play for Today or the short BBC2 strands Thirty Minute Theatre (1965-73) and its regional spin-off Second City Firsts (1973-78). Rose's relatively autonomous position within the BBC helped launch talent, including Alan Bleasdale, David Hare, Jack Rosenthal and Willy Russell, and visionary pieces like David Rudkin and Alan Clarke's Penda's Fen (1974).

More detail on BBC Birmingham can be found in Rolinson (2005), but my focus here is on the sense that emerges of a shared aesthetic under Rose, a rich regional culture which is comparable with regional cinema culture and which opens opportunities for examinations of the interplay between film and television studies. ${ }^{3}$ Stylistic continuities across Land of Green Ginger and Penda's Fen are partly explained by crew rotation (both share lighting cameraman Michael Williams), but there are continuities across so many pieces - including Clarke's Horace (1972) and Leigh's Hard Labour (1973) - that there is a sense of something approaching a movement. These $16 \mathrm{~mm}$ films share shooting styles that combine observation and aestheticisation, restrained framing, pared-down narrative and other devices comparable with markers of developments in cinematic 'realism' (Italian neo-realism, Czech social cinema) and art cinema (Bresson, Ozu). James Saynor (1992: 28-31) identified continuities across Rose's work, for the BBC and Film on Four, related to regional space: an "intense amalgam of realism and fantasy' within which Rose's work responded to 'the "need" of a concrete locale combined with the writerly "leaping" of a talented 
dramatist'. This 'leaping' stressed individual vision: continuity, not uniformity. In Gangsters (1975, 1976-78), writer Philip Martin tackles racial tensions, crime and drug problems in Birmingham, but does so through post-modern approaches to genre and storytelling. Boys from the Blackstuff (1982) is justly acclaimed as a key text on unemployment, but Alan Bleasdale exploits serial form to write with rich tonal variety across the episodes.

Land of Green Ginger has obvious regional markers in terms of background. Its writer was 'born in Jarrow and then brought up and educated in Hull', as he told a Labour MP: 'Beat that for credentials' (Plater 2000: 68). Alongside a long television career, Plater has written many regional theatre plays, including Hull City plays, one of which The Tigers are Coming - was reworked by Willy Russell as When the Reds Come Marching In for a Liverpool audience, after which Plater wryly noted that 'I'm the only writer ... who has to be translated from one part of the country to another' (Mason 2004: 4). Land of Green Ginger demonstrates BBC Birmingham values, such as the centrality of Plater's personal voice, amidst a willingness to engage with identity beyond simply recording a 'real' location. Indeed, Rose opposed tokenistic drama:

I could have said to Brian Finch, 'you come from Wigan, so write me a play about Wigan', or to David Rudkin, 'Let me have something about Warwickshire.' But there would have been little point in that. What each writer has done is to mirror some aspect of a community which he knows intimately. The locality is only important in so far as it provides the setting for a situation. (Campbell 1972: 10)

Close analysis of Land of Green Ginger, which Barry Hanson (2000: 62) argued was 'the kind of work we felt we had been placed at Birmingham to do', will address some of the complex ways in which English Regions Drama creatively 'mirrored' a 'community'.

\section{Land of Green Ginger: Introduction}

Land of Green Ginger was first transmitted on BBC1 on Monday 15 January 1973 between $9.25 \mathrm{pm}$ and $10.15 \mathrm{pm}$. In the play, Sally (Gwen Taylor) returns to her hometown of Hull for the weekend from London, where she now works. Having received an offer to work abroad, she considers her future with trawlerman boyfriend Mike (John Flanagan). The play is concerned with ideas of regional identity and 'home', forced relocation within cities and away from cities for work. Sally's exploration of her hometown mirrors her engagement 


\section{Dave Rolinson}

with her sense of self, and themes of loss and community are rooted in the play's depiction of the city's old fishing industry and a nuanced use of actual landscapes.

The play's minimalist, apparently episodic narrative should not mask the richness of its detail or the structural complexity through which Plater explores ideas and creates atmosphere. To elucidate that complexity, this article tackles key sequences in a linear chronology: for instance, the subtlety of the shifting use of 'incidental' music is acknowledged by discussing its changing effects throughout the play. The music scores and comments upon atmosphere and structure, and demonstrates BBC Birmingham's characteristic engagement with regional identity on a cultural level.

My privileging of Plater's contribution is not intended to denigrate the contribution of director Brian Parker but to highlight the closeness of their collaboration. Plater advised on Hull locations, and his script is highly visual, determining types of shot whilst indicating that some of its connections between songs, words and images (which are discussed throughout this paper) 'can only be done during production' (Alan Plater Papers). ${ }^{4}$ Discussions of the significance of local landmarks support Plater's engagement with characterisation and themes of architecture and community: their effectiveness does not depend upon the viewer's knowledge of actual local geography.

\section{'Mysterious Northern Mist': Opening Scenes}

Described in the script as an 'overture', the play's first four minutes move between Sally boarding her train at King's Cross station in London, Mike returning to Hull on a trawler, and images of the city to which they are returning, all scored by folk music arranged by The Watersons. The soundtrack builds atmosphere, shapes the narrative and provides the images with thematic resonances. Over shots of Sally boarding her train, the traditional song 'A North Country Maid' establishes that 'A North Country Maid up to London hath strayed/ Although with her nature it did not agree/And she's wept and she's sighed/And she's hung her head and cried "How I wish once again in the North I could be/Where the oak and the ash and the bonny ivy tree/All flourish and bloom in my North Country"'. Plater (2006: 81) argued that the play's 'origins' were in this song.

A folk group comprising mostly family members, The Watersons had re-formed in 1972 after disbanding in 1968 following five successful years. Like Plater, The Watersons were acclaimed for work rooted in regions. David Suff (2003: 3) locates their musical identity within their 
home city: 'Hull ... had a thriving local culture that itself was a product of a paradoxical combination of port life - that cocktail of cosmopolitanism and shore leave ... and the sort of geographical isolation that nurtured and nursed local folkways'. After early work influenced by skiffle and more readily available American influences, The Watersons aspired to 'locally reared musical sustenance' and 'actively sought out a distinctive local Yorkshire repertoire' (ibid.: 4).

Also seeking a local repertoire, Plater, as he recalled in interview, 'went round to the Watersons' house ... told them the story ... [and asked for] songs that will illustrate these ideas'. ${ }^{5}$ The Watersons made 'the useful point that most sea songs are not specific to any particular area ... travelling the world, [singers] would just change the names of the pubs and [people] to suit where they were'. Therefore, 'Homeward Bound' is adapted from published versions (see Palmer 1986: 187-8) to match both narrative ('here comes Mike with his three weeks' pay') and locale (referencing 'the Old Blue Bell', a pub at which The Watersons used to perform) ${ }^{6}$ The script itself works within that tradition, for instance using such a folk-standard character name as 'Sally'. Despite researching all the songs used in the play, I will restrict myself to closer detail of 'A North Country Maid' as an indicative piece. It is impossible to conclusively trace the origins of these songs: folk performers unearth songs from archives, libraries and memories of performances and traditions. Comparably with Plater's project and that of BBC Birmingham, folk revivalists faced the difficulty of self-definition: Watersons member John Harrison recalled 'learning our bloody heritage through the American Embassy!' (Suff 2003: 20)

The start of the chorus, 'Where the oak and the ash', motivates a cut from Sally to images of Hull: the docks (with shots of trees accompanying 'the bonny ivy tree') and the market, which at that point was located in front of Holy Trinity Church in Hull's Old Town (with shots of the church accompanying 'Where the bells they do ring'). However, the regional resonances of this are complex, given that the song is not specific to Hull. The song's origins are difficult to trace: it appeared in slightly different forms (as 'The Northern Lasse's Lamentation' or with lyrics such as 'A North-countrie lass up to London did pass') and the tune pre-dates the words. For instance, A.L. Lloyd (1994) noted that it 'started life as a dance tune, found in many places and ... titles' including 'Sir James Hawkins's Transcripts of music for the virginals' and The Dancing Master of 1650 'under the title "Goddesses"'. According to Lloyd, the refrain 'in all its home-sick nostalgia' appears in other songs including 'Home, Dearie Home', and when it occurs during Sir Walter Scott's Rob Roy (1817), with Mabel singing 'Oh, the oak, the ash, and the 


\section{Dave Rolinson}

bonny ivy tree,/They flourish best at home in the North Countrie!', it is described as an 'old ditty' referring to Scotland. As early as 1859 William Chappell charted a complex lineage through versions in different collections, including 'The Dumb Maid', an earlier version of 'There Was a Bonny Blade', or 'The Lancashire Lovers', meant for different tunes including 'The Duke of Norfolk' ('But alack! And alas! she was dumb, dumb, dumb'). The idea of a broader regional culture, into which more specific references are inserted, reaffirms Plater's project. I will return to this idea of folk music drawing from community tradition when it is problematised later in the play.

This soundtrack plays over documentary-style 'grab shots' of everyday traders and customers in the market place. These people are unconnected to the narrative, some looking directly at the camera and others observed on long lenses, gossiping or putting vinegar on their chips on Trinity House Lane. Despite changes to Hull's architecture in recent years - the filling-in of docks, the pedestrianisation of streets, and the addition of new landmarks like the Prince's Quay shopping centre - it remains an evocative portrait of the Old Town. Plater studied architecture, and wrote a piece in the Port of Hull Journal in 1962 (anthologised in Plater 1975) which foreshadows the visual style of this sequence:

The Old Town of Hull is easily the most exciting and vital part of the city, an area where commerce, recreation, ships, big business, shopping and civic administrations all intermingle ... Holy Trinity Church, fine building though it is, receives less attention than the market stalls lying before it. A stranger with alert senses can learn more about the city of Hull by walking along High Street, Bowlalley Lane, Blanket Row, Humber Dock Street and the others than he could from a dozen guide-books and brochures; but he learns by watching the people, not from gazing in awe at selected monuments as if they were exhibits in a museum.

The scene duplicates this idea, beginning with architecture - the Kingston corner pub loomed over by the Church - before the camera moves to find the market place.

Several reviewers thought these observational and romantic qualities conflicted - Sylvia Clayton (1973) wrote of this sequence: 'It can hardly be said that the meadows and maidens looked pleasant and gay, as in the ballad' - but this conflict runs throughout depictions of Northern spaces in other cultural contexts, as we shall see. The dominant reading of romanticism is governed by the interplay between images and soundtrack, as the yearning established by the lyrics provides these images with character interiority (Sally's 'wish' to 'again' be 'in the North'). Plater (2006: 81) recalled trying to 'set the plaintive lyricism of the song in deliberate contrast to the bleaker realities of their situation ... Her 
dilemma is that she isn't prepared to marry a man whose life will be dominated by three-week-long trips to Norway, with no guarantee that he'll come back.' Therefore, the play again cuts between Sally and Mike's journeys back to Hull, again triggered by the soundtrack: a match-cut between Sally sitting on the left of frame looking out of the train window and Mike standing on the left of frame on the trawler looking out to sea.

Dialogue on the train addresses this romanticised image. Sally meets Reynolds, a journalist travelling to research an article about Hull and the surrounding region. ${ }^{7} \mathrm{He}$ claims that Hull people 'have this mysterious Northern mist behind their eyes' (Sally replies that it 'takes a clever feller to talk rubbish like that'). When Reynolds says Hull is his 'favourite' region so far, Sally responds: 'Lucky old us', which is quite an ironic opening statement within a play from English Regions Drama. Reynolds also asks about the Land of Green Ginger, a Hull street which is also the name of a magic city (I will return to this later), therefore highlighting the interrelationship of observationalism and romanticism. Indeed, the script outlines this quality when describing a shot: 'If it's a little misty and magical that's all to the good: you don't expect cold reason in a town that calls a street Land of Green Ginger'. Moreover, Reynolds argues that, having 'lived in about a dozen places', he has come to 'envy people who know where home is', an argument that foreshadows Sally's attempt to 'know' where 'home' is.

Plater was aware of antecedents for regional depiction, which extends to his ear for dialogue. In interview, he recalled Joan Littlewood's work in Hull around the time of the Second World War: 'She said you could walk the streets of Hull and hear the people speaking poetry ... She didn't mean iambic pentameters, but that in all regional accents there is a kind of poetic element.' He cited the north-eastern collective Amber Films and the work of Tyneside writer Tom Hadaway, whose television work included God Bless Thee, Jacky Maddison (1974) for Centre Play and early episodes of When the Boat Comes In (1976-81). In an obituary for Hadaway, Plater (2005) quoted him: 'If our betters shame us out of our phrases and pronunciation, we shall be without resource. From a shared history, dialect is the enabling power of the commoner.' Ideas of shared history, dialect and the preservation of regional identity run through this play's form and content.

\section{'Removed lives': the death and life of great Northern cities}

In Hull, Sally takes a taxi from Paragon Station to Bransholme, a council estate to which her mother has been relocated following the 


\section{Dave Rolinson}

demolition of their old family home in the Hessle Road area, centre of West Hull's fishing community. Comments by the taxi driver and bleak low-angle shots of tower blocks heighten Sally's mother's isolation. Miles from her old community, she is without her husband who is working in the Persian Gulf. Sally's mother makes the best of her new home and tells her daughter to work wherever she can, but one multi-layered shot explores the unspoken tensions in the scene. With Sally standing at the window looking out at the estate, we see a reverse-shot of Sally's mother. She looks ahead towards Sally, who is out of frame, but there is a mirror next to Sally's mother, which reflects Sally's back. This slightly disorienting shot plays with ideas of space, looking forwards and backwards (enhancing the yearning quality of the mother's gaze) and a character turning her back on her mother. In the bottom right corner of the mirror there is a postcard from the Gulf, a rectangular portrait of a location which echoes the mirror in which are reflected an image of Bransholme and Sally, who works away like her father does.

When Sally leaves for the day we get, according to the script, 'a cool, brief look at [her mother's] loneliness'. A melancholy shot of her alone in her flat is heightened by the low-key humming on the soundtrack. To slightly misuse Philip Larkin's poem 'Here' (2003: 79-80), she is one of those living 'removed lives', 'dwelling/Where only salesmen and relations come'. This loneliness is underlined in the contrast between this sequence and the next, in which Sally visits her old Hessle Road community. The residents here, like the earlier market customers, also echo Larkin's 'cut-price crowd, urban yet simple' (if that line is interpreted as the imaginative sympathy of a preoccupied observer towards the everyday, rather than the frequent reading of Larkin's expression of condescension). The humming introduces a song ('If All the Young Men Were as Hares on the Mountain') which becomes much jauntier over images of Hessle Road, just as the frames become busier and the cutting quicker.

Brian Parker here utilises drama-documentary technique to integrate the fictional character of Sally into the regional space. Sally walks across Hessle Road, filmed from a high angle on a long lens, from which she seems part of the community rather than a privileged lead character, subject to 'grab' shots of the kind that record real-life passersby. This is heightened through visual rhyme: a mid-shot recording a young woman walking down Hessle Road is followed seconds later by a shot of Sally composed almost identically in the frame. We note details, including streets off Hessle Road that share their names with public schools, a detail which Plater (1975) also commented upon in his poem 'Names': 'Names/Street names: Eton, Harrow, Rugby/Homage to 
distant headmasters/Not that they realise it'. Further emphasising her mother's isolation, Sally turns a corner and collides with Mrs Thurlow, Mike's mother. She has not seen Sally's mother since the latter moved to Bransholme and would not like to move to a big estate because she would be unable to walk around and speak to people - a point supported by the aforementioned stylistic contrasts between the Bransholme and Hessle Road sequences.

If the Hessle Road back-streets and Mrs Thurlow's cameo ('Bugger the shopping - I was only off for a bag of sugar and a bit of scandal') recall the British New Wave, it is worth pausing to consider how the depiction of the North so far has featured a rich interplay between observational footage and romanticised aestheticism. After all, this is replete with familiar critical tensions, the hostility of V.F. Perkins and the Movie tradition to the British New Wave built, as G.F. Taylor (2006: 14-17) summarises, upon the view that 'these films were unable to connect their characters effectively with their environments'. From the work of Andrew Higson and others, Taylor argued that 'New Wave narratives require these spaces to be active rather than passive', dramatic spaces but also spaces which 'authenticate the fiction by being easily read as real historical places'. In Land of Green Ginger, as in the New Wave films discussed by John Hill (1986: 127-36) in response to critics such as Perkins, the display of place differs from conventional narrative films in that place does not seem to be a 'setting' for narrative action - instead the narrative action appears insignificant and enables a display of place. Newspaper critics echoed this, with Leonard Buckley (1973) arguing that 'this was not so much a play as a montage of Hull with a lecture on the life and problems there. The setting was evidently more important than the plot'. Similarly, James Thomas (1973) asked whether 'getting the TV cameras out on full-scale location' is 'in danger of becoming a substitute for a good play'. Thomas argued that Hull was 'not the prettiest background against which to spread a romantic interlude among the fish cranes, the rusty boats and the decrepit, abandoned wharves'.

Film history is littered with criticisms of depictions of actual places (particularly Northern locations) as exploitative bourgeois aestheticism. Land of Green Ginger's combination of 'documentary' style and romanticism brings to mind debates on documentary which query the possibility of 'pure' observationalism without aesthetic or narrative mediation, and the criticism suffered by, for example, Humphrey Jennings for his depiction of the North in Spare Time (1939) and his poetic style in general. The Hull scenes demonstrate 'life caught unawares' as in Dziga Vertov's phrase, but Vertov's highly valued obser- 
vationalism was itself one part of a reflexive 'kino-eye' project. There are also dangers of dour, negative depictions of the North, as Alan Clarke told Mike Hutchinson (1987) following his unflattering portrait of Bradford in Rita, Sue and Bob Too (1987): 'What I can't stand is the kind of film-maker who scoots up North, shoots a film about how depressed things are ... and encourages "the natives" ... "Great! I like it! Keep things bad! ... I'll be back next year!"' Land of Green Ginger lacks the expressionistic or politically discursive approach to regional space in, for instance, Clarke's Road (1987), but it explores rewarding tensions in its use of landscape. There are New Wave parallels - when Mike and Sally visit Pickering Park and play in their old childhood haunts there is an echo of the New Wave motif of 'escape' into the 'countryside' - but also the locations combine the complexities identified by Taylor in response to Perkins and others: psychological, metaphorical, 'authenticating' but also increasingly formal.

There are other reference points for this regional depiction, particularly the poetry of Philip Larkin. In interview, Plater discussed the origins of Land of Green Ginger as a piece written for a mooted ITV strand called A Tale of Six Cities. This play would have been called The Surprise of a Large Town, using a line from Larkin's poem 'Here', from which Plater was going to quote 'as a kind of musical chorus' (he checked copyright with Larkin's publisher). Ultimately the revised Land of Green Ginger version uses the music of The Watersons to achieve this, but the influence of Larkin remains. This opens up different reference points for Plater's combination of the observational and the romantic: take Andrew Motion's (1982: 19) description of Larkin's place within the poetic tradition, alongside those who are "concerned with the relationship between themselves and their towns and landscapes, and habitually express a sense of communion with their surroundings in exalted or even semi-mystical terms'. The aforementioned literary and cinematic reference points usefully contextualise the combination of realism, lyricism and surrealism that drew Plater's self-portrait as a 'gritty Northern surrealist' or his comment in interview that 'there are two types of writers: those who look out the window and those who look in a mirror. The ones who look in mirrors tend to be poets'. ${ }^{8}$

Plater tackled comparable subject matter in theatre plays such as Tales of Humberside (1975) and Don't Build a Bridge, Drain the River (1970), which also included music by Mike Waterson, but, accepting that a nationally networked slot is a different platform from his regional theatre plays, Plater added 'explanation' of moments that 'the audience outside of Hull won't understand' and agreed 'compromises' over casting. The central roles went to Taylor and Flanagan, relative 
unknowns but outsiders using more generic 'Northern' accents, even if reviewer Nancy Banks-Smith (1973) still complained that 'the speech resembles a slap in the face with a wet fish'. However, at Plater's suggestion, supporting actors were locals. Previewer Yvonne Thomas (1973: 11) who profiled Ivy Cawood (Mrs Thurlow), 'organist at the Belmont Club' and 'mother of a vicar' and Clive Hunter (taxi driver), 'organist and gaff-man at the Three Tuns', recognised 'some very wellknown faces from clubland' in the play. Cawood 'never did any acting before', and 'behaved for the camera just as she always does', while Plater in interview recalled knowing Hunter from the latter's job in a Hull music shop. Casting inexperienced locals to react in line with their way of life rather than 'act' a performance has cinematic roots (including Italian neo-realism) and is shared by this television generation. As with Ken Loach, these are club performers with union recognition.

Following a brief meeting with Mike (on his way to a rugby league match), Sally explores the bulldozed ruins of her former family home. She is framed in a remaining doorway, her sense of home as devastated as the building itself. The location accurately represents the clearance of old housing in this area but also serves metaphorically to underline the decline of the old fishing industry and the old Hessle Road community which grew out of it. Her impractical red shoes bring to mind The Wizard of $\mathrm{Oz}$ (1939), another film about the search for a mystical city; for Sally there seems to be no place like home. Further undermining the extended family of the community, Sally sees 'Uncle Jack', a trawler skipper returned on the same day as Mike, drunk and crying. The soundtrack again adds nuance, with the mournful 'A Sailor's Life' narrating a girl's search for her boyfriend, who may have drowned at sea, adapted for impact: lines such as 'Does my sweet Michael sail among your crew?' differ from the 1899 version compiled by Ralph Vaughan Williams and A.L. Lloyd (1969: 123).

The rubble here is a limbo between the Hessle Road and Bransholme communities. This underlines Plater's concern with the 'lack of understanding by the people who make the decisions ... on how communities work'. Plater (1975) argued that '[ $t]$ he shapes and forms of architecture are a direct result of the human activity carried out in and around the buildings; these, together with the streets which separate them and at the same time bind them together - form the background to the pattern of life in the community'. Recalling research into an unmade project on diasporas with Lenny Henry, Plater noted in interview that 'the history of the world is a history of great migrations' and argued that 'migration is crucial to understanding how some communities', in Hull and other Northern industrial cities, 'disintegrated'. He believed that 


\section{Dave Rolinson}

'something was lost when people were moved out' and that 'forced migration ... never made people happy, ever in the history of the world'.

As well as noting a moving example of forced migration within Hull from Tom Courtenay's memoirs (2000), Plater referenced Jane Jacobs' pioneering urban planning study The Death and Life of Great American Cities. Jacobs (1961: 5) argued that 'people who get marked with the planners' hex signs are pushed about, expropriated, and uprooted much as if they were the subjects of a conquering power', and made many recommendations and criticisms which are subsequently raised by this play: the need for walkable streets, estates 'rewoven back into the fabric' of cities and the need for commercial, cultural and social 'diversity' (ibid.: 392) rather than the demarcation of certain areas for selected purposes such as 'cultural zones', because these policies were not 'rebuilding' but 'sacking' cities (ibid.: 3). In a wider sense, 'diversity' seems even more vital now that, as Plater noted in interview, the same franchised stores are making our city centres uniform. One central point of Land of Green Ginger, for Plater, is that 'there isn't anywhere like it ... whether it's Hull, or Newcastle, or Gateshead. These places are all unique, and we should cherish their uniqueness'. Indeed, in the year of the play's transmission, Plater (1973: 733) set distinctive Hull characteristics against standardisation through bureaucracy and the buying-up of local shops.

Having established several disparate areas which Sally has struggled to connect, the play enters a pivotal set of scenes constructed upon literal and metaphorical bridges.

\section{'When the Bridge is Built': Spatial Communities}

Mike takes Sally to Hessle Foreshore to see where the Humber Bridge was due to be built by 1976 . Throughout, shots of Sally and Mike looking out at the Rivers Hull and Humber shows the influence of Larkin's 'Here' at its clearest - indeed, the script paraphrases it: 'And the widening river's slow presence,/The piled gold clouds, the shining gull-marked mud,/Gathers to the surprise of a large town.' According to the local media, this impressive suspension bridge will bring prosperity to the area. Mike's speech echoes Plater's own statement that the bridge would produce a 'boost [that] will be psychological, tinged with mysticism' (ibid.: 733). The likelihood of the bridge ever being completed was joked about locally and in Plater theatre pieces such as Tales of Humberside, but it opened in 1981 and features briefly in Plater's The Beiderbecke Connection (ITV, 1988). ${ }^{9}$

The bridge also reflects Sally and Mike's attempts to bridge their 
relationship: Mike claims that he will leave the trawlers 'when the bridge is built'. But introducing this landmark at this stage of the narrative brings other connotations: bridging home and work (Hull and London), old and new communities, childhood and adulthood, and the sense of the bridge as, in Plater's phrase in interview, 'some mythological future when it's all gonna be alright'. The couple spark off each other with witty dialogue, and the scene epitomises the way that the play, according to praise in the Audience Research Report, makes "excellent use of [camera work and] Hull locations to give "visual reinforcement" to the feelings of the two young people' (BBC WAC). The scene is itself bridged by the start of the Watersons performing 'I Am a Rover', as Mike and Sally drink in the Alexandra Hotel, a pub on Hessle Road. The lyrics fit the wordless sequence - 'I am a rover, seldom sober ... It's when I'm drinking, I'm always thinking/Of how to gain my love's company.' Michael Colbert (1973) argued in the Yorkshire Post that 'Plater was adroit in his use of folk ballads ... this singing, with words matching the dramatic movement, was placed with artistic perception rather like the punctuation marks of a chorus in Greek tragedy.' Not everyone appreciated this: Sylvia Clayton (1973) would have preferred more Plater to the 'plaintive monotone' of the Watersons whilst an audience sample felt that the 'dirge-like singing ... broke up the action' (BBC WAC). However, such complaints founder when the use of music is as complex as it is in this sequence.

The play cuts from the Alexandra to the Haworth Arms, where the Watersons are performing this very song. Indeed, a jarring cut underlines the fact that the music, which has seemed non-diegetic, has in fact been diegetic. In interview, Plater described this cut as his 'favourite moment', as it implies that 'these are real people ... part of the same community'. This cut roots the play in a continuity of experience and community with political overtones. John McGrath's The Cheviot, the Stag and the Black, Black Oil (1974) is a useful reference point. Lez Cooke (2003: 193) described it as 'a unique amalgam of theatre performance, historical reconstruction and documentary footage' which, in keeping with the political themes of the 7:84 Theatre Company, formed a 'dialectical montage'. Land of Green Ginger is clearly not attempting McGrath's Brechtian political form, the critical realism called for during the Screen debates of the 1970s. However, in its use of the Watersons during moments such as this, the play echoes concerns with history through structures reinforced by the use of music.

For instance, McGrath told Lez Cooke (2003: 105) that he consciously attempted to cover 'two hundred years of history' even though 'television naturalism can't do that', and in notes on his play, McGrath 


\section{Dave Rolinson}

(1981: x) discussed the importance of form in the communication of ideas, including the gathering known as the 'ceilidh', which includes performance, participation and traditional regional music. Continuity of history and culture recurs in several plays from the period, and I have discussed (Rolinson 2005) the evocation of regional landscape through cultural layering and Elgarian resonances in Penda's Fen. Comparably, reviewer Peter Black (1973) argued that Land of Green Ginger was most successful for capturing 'the flavour of a defiantly local tradition'. The folk music roots the play in conceptions of landscape through its content, but also its form, given the resonances of tradition and community.

Plater is often associated with music that reinforces situation and character, particularly jazz, which is memorably used in the Beiderbecke stories. BBC4's 2005 documentary on Plater was understandably subtitled Hearing the Music, and discussed his use of music including the sense of jazz as metaphor in Misterioso (1991). Plater (2006: 82-3) has argued that "most music in film and television tends to be called [accurately] ... "incidental". It underlines the moments - scary bits, sad bits, look-behind-you bits. It tells the watchers what they should be thinking and ... feeling ... on the assumption that they're too stupid to work it out for themselves. In Land of Green Ginger the music did more than this'. In keeping with productions cited by Plater - The Third Man (1949) or work by Dennis Potter or Woody Allen - the music 'not only reflected the action, it helped to generate and inspire the action. Instead of being glued on afterwards, it was written into the script more or less from the first draft stage'. Nancy Banks-Smith (1973) described Land of Green Ginger as 'not so much a play, more a local musical: plaiting script, songs and scenery in about equal amounts'. The movement between the scenes I have just discussed, reinforced by music, in effect 'plaits' region, history and community. Furthermore, the adaptation of lyrics underscores the narrative in terms which locate the characters' central dilemma in a more politicised space, establishing themes to be developed later: '[T] he cock's a-crowing and I must be going ... for I am a servant and I must obey'.

Mike and Sally then walk around Hull's Old Town and the Humber Dock Basin (a walk which Plater drew on the back of the script). Sally now suggests looking for the Land of Green Ginger. Though it is never shown in the play, Land of Green Ginger is a small street in the Old Town best reached on foot at the top of the historic shopping street Whitefriargate. The street's name is centuries old and its exact meaning is lost. ${ }^{10}$ Local knowledge underlines the irony here: Mike dismisses the idea of a search even though the street is barely a minute's walk away. 
This echoes the scene in Winifred Holtby's 1927 novel The Land of Green Ginger, in which young Joanna and aunts Kate and Emily find, but do not enter, the street (albeit via semi-fictionalised detail: Holtby places it at the end of Friarsgate in Kingsport). In wonder, Joanna describes it as a 'dark, narrow, mysterious road to Heaven, to Fairy Land, to anywhere', and is disappointed to be moved on as if 'like Moses they would look at the Promised Land and never enter it' (Holtby 1955: 18-21). Sally (who, in an echo of Joanna, described Hull to Reynolds as 'the Promised Land') and Mike spend the next few minutes of screen time walking away from that location, emphasising that the search is more metaphorical than literal. ${ }^{11}$ This also echoes Noel Langley's 1936 children's story of the same name, in which Aladdin's son Abu Ali seeks out the Land of Green Ginger, a changing, literally floating land. It is tempting to compare Sally with Langley's magician who thought he 'could take the Land of Green Ginger with him like a portable kitchengarden', but after 'something went wrong', he 'had never been able to turn himself back' (2005: 10). Although Sally has not (like the magician) been turned into a button-nosed tortoise, she too faces difficulty turning back emotionally or geographically. The parallel is strengthened by the play's echoes of The Wizard of $O z$, whose screenplay was co-written by Langley.

Building upon the historical layering provided by the Watersons' folk revivalism and the distance shots which stress the city's medieval architecture (the city was founded in the late twelfth-century and the Holy Trinity Church was built in the thirteenth-century), Mike and Sally stop at the statue of King Billy on Lowgate/Market Place. The statue commemorates William III of Orange, credited as the founder of the 'modern' city of Hull after his 1688 victory over James II in the 'Glorious Revolution', and symbolises Hull merchants' resistance to attempts to increase outside interference in the city. Histories of the early days of the English Civil War include Hull locking its gates to Charles I in April 1642 (Morrill 2001: 363). The seventeenth century was a period of civil wars, of changes in the regional nature of politics and economics and a successful but short-lived attempt to make England a Republic. Therefore, cultural and historical resonances have variously related Hull to ideas of obedience ('I must obey') and, as if in rebuttal, disobedience and independence (King Billy). The fact that Billy's statue stands near a Job Centre is a useful historical accident for this reading.

At the docks, it emerges that Mike has a boat to skipper - taken from Uncle Jack after his poor luck catching fish and attained through backhanders apparently given during the Alexandra pub scene. Sally wants 
to return to Hull, where she can 'walk down the street' and know people, but Mike will not give up fishing for a safer but potentially less stable shore job. Sally's fears are understandable: Plater (2006: 82) noted that 'Hull was still living in the shadow of 1968 when three trawlers - the Ross Cleveland, the St Romanus and the Kingston Peridotwere lost within a ten-day period', and Alec Gill (1989) observed the loss of 900 ships between 1835 and 1987, an average of six vessels every winter. Pragmatic survivalism in the face of a constant awareness of danger, of the kind articulated by Mike here, is persuasively discussed in Gill's social history of the Hessle Road fishing community (Gill 2003).

However, Land of Green Ginger also addresses work in general. The titular street becomes a metaphor for the distant prospect of a reconciled relationship, but also (taken in conjunction with the statue) something closer to the political ideology often associated with drama in this period. The final episode of Boys from the Blackstuff, 'George's Last Ride', is justly praised for the sequence in which the old Labour activist George Malone gazes out at the redundant Albert Docks in Liverpool, a scene which 'enabled parallels to be drawn between past and present', prosperity and decline, mass union activism and Thatcherite individualism (Cooke 2003: 132). This brings to mind the late scene in Land of Green Ginger in which Mike gazes out and comments on the 'flaming redundant' docks, while Sally comments that the work has been taken down river. Like the play's characters, the work has moved elsewhere for invisible reasons of politics and economics. The scene lacks the overt political commentary of Bleasdale's work, but it comes in a play that has rooted itself in community experience. Mike's comment that 'nowt's changed since King Billy' may comment on the static nature of Hull, but also locates his own working experience within a political tradition (like Hull around Billy's time, Mike intends to be 'my own man'). Sally asks: 'Why shouldn't people do decent jobs and have decent lives and live where they want to live?' and Mike replies: 'We let them get away with it because we don't know any better'. The jarring effect of this speech is comparable with the cut to the Watersons mentioned earlier, a sudden infusion of perspective on a seemingly straightforward linear narrative. The narrative has epitomised day-to-day lived experience with no political engagement, yet this now becomes a defining absence, underscored by the fact that the apparently linear rhythms of the narrative have been shaped by work and its lack (the explanations for Jack's tears, the Alexandra scene, and a possible class reading for the seemingly incidental detail of the Eton, Harrow and Rugby street signs). 
The play implicitly addresses opportunities and identity in a political sense. As Plater (2006: 82) argued, the lead characters are 'locked into the reality of lives determined by how they make their living'. This is one of the meanings of 'home' in the play. On the train back to London, Reynolds asks Sally whether she found the Land of Green Ginger and Sally replies that they didn't look hard enough. With Sally and Mike having failed to move on, the ending returns us to Sally aboard the train and Mike aboard his trawler, and the end credits over shots of a trawler echo the opening credits. The circularity here, viewed in the context of Mike and Sally's final conversation, provides a sense of frustrated potential and movement, which provides new ways of reading earlier scenes: for instance, when Mike arrived in his new car but said they were 'not going nowhere', and the cut between Sally and Mike which might now seem less a romantic connection than a fatalistic repetition anticipating their lack of movement.

This provides a useful response to criticisms of the play's pared-down narrative. The BBC's Audience Research report cites some excellent responses but also 'somewhat cool' responses criticising 'the lack of a strong story line and scarcity of dialogue' which 'made it seem more like a documentary than a play'. However, this is another element of the aforementioned shared aesthetic in BBC Birmingham and related drama, an approach to narrative akin to that proposed by André Bazin and Italian neo-realist thinker Cesare Zavattini, screenwriter of Bicycle Thieves (1948), a film whose plot also involves two characters walking around a city in search of something they do not find. In my book on Alan Clarke I discuss, and conduct ideological analyses of, television dramatists' neo-realist narrative tendencies - inverting the classical use of characters as functionaries of plot and attempting to capture everyday life without embellishment. In interview, Plater recognised the impact of these reference points, recalling Ermanno Olmi's The Job (1961) amongst other films, but also the narrative features of the theatre of Anton Chekhov: 'Not a lot goes on in Chekhov, except you see the entire bleeding world on the stage in front of you'. Plater has 'always been a bit resistant to conventional narrative', being more interested in 'people being' than 'people doing', with 'digging into their lives' rather than 'inventing stuff to happen to people'. His script for the final episode of the fifth series of $Z$ Cars, 'That's the Way It Is' (1965), startled reviewers with its lack of interest in conventional narrative. Therefore, the criticism that the play privileged atmosphere over plot underplays the complexity of the construction. 


\section{'The Real Love Story': Conclusion}

Ironically, it was in Hull that this depiction of regional space was most controversial. In the Hull Daily Mail, there were complaints that the play concentrated on the fishing industry and themes of decline. Indeed, the broad caricatures in John Sullivan's Only Fools and Horses episode 'To Hull and Back' (25 December 1985) imply that this large city has become indistinguishable from its docks. Plater became familiar with complaints that he should have talked about the city's successful areas: the play was screened at Hull Truck theatre with a question session organised by Jim Hawkins, covered on local radio. Plater gave a talk for the Hull Civic Society at the Ferens Art Gallery on 'Hull on Television', during which he rejected public relations agendas and insisted that the play was 'written out of love for the city'. He stated that: 'If a retired Brigadier from Eastbourne might think that Hull smells of fish it ... will not affect my way of life at all' (Anonymous 1974). In interview he dismissed the view that 'a big industrialist' planning to 'build a big factory in Hull' would think, 'before I do, I'm gonna watch this play'. These complaints should be weighed against an unrelated non-fiction piece written for The Listener in which Plater (1973: 733) listed some of Hull's successes to balance the city's tendency to be 'over-modest', and described himself as 'a self-confessed, starry-eyed lover'. Indeed, as Nancy Banks-Smith (1973) wrote, the play's 'real love story was evidently between the playwright and the city'.

In interview, Plater acknowledged the tonal difficulty of a piece whose script requested a 'misty yet magical' yet recognisable city, but he and I agreed that director Brian Parker achieves it. The play could work as social history alongside, for instance, local historian Alec Gill (2003), who began taking photographs of Hessle Road residents during the 1970 s. $^{12}$ This paper has sought to do justice to the aesthetic and cultural complexity through which the play achieves its beautiful evocation of regional place. Viewed today, the play has the quality of elegy, partly for a nostalgic sense of the city's past, partly for the sense of the 'unique' nature of British cities mentioned earlier and arguably lost to geopolitical shifts under globalisation, but also for a form of television single drama of such indigenous scope, opportunities for which have subsequently narrowed.

\section{Acknowledgements}

Thanks to Alan Plater and Shirley Rubinstein for welcoming me so warmly into their home in London on 3 July 2006 for an interview. For 


\section{'The Surprise of a Large Town'}

help with document research, thanks to John Williams, Karen Devlin, the Brynmor Jones Library at the University of Hull, BBC Written Archives Centre, and the British Film Institute Library.

\section{Notes}

1. My focus on the BBC should not obscure the importance of ITV's regional companies. See Johnson and Turnock (2005), Lez Cooke's work at Manchester Metropolitan University for the AHRB-funded project 'Cultures of British Television Drama, 1960-82' and Natasha Vall's work at the University of Teeside within the North East England History Institute, including the paper 'Television and the legend of hardship in North-Eastern England' at the University of Hull's Literary North conference, 2006.

2. For instance, Play for Today staged crucial theatre pieces by David Hare, Howard Brenton and David Edgar. For more on English Regions Drama in this context, see Cooke (2005 and 2007).

3. This period also saw British cinema engaging with distinctive approaches to regional space and identity, for example in the work of directors such as Terence Davies and Bill Douglas, financed by the British Film Institute Production Board, and various radical or 'minority' film groups and workshops such as the Leeds Animation Workshop.

4. All script quotations are taken from the unpublished script by Alan Plater, accessed within the 'Alan Plater Papers'.

5. This and all other quotations, unless otherwise stated, are taken from an interview with Alan Plater by the author on 3 July 2006. For a further Plater interview with a regional inflection, see Yorkshire TV's Images of Yorkshire: Alan Plater.

6. See the 1966 documentary Travelling For a Living.

7. This scene appeared in script form in a collection of Plater's Hull-themed work to celebrate the first five years of what was then called Humberside Theatre (Plater 1975).

8. Motion (1982: 15) discussed Larkin's interest in both Yeats and Hardy as representing "that struggle between two different literary traditions which has dominated English poetry ... the "tradition" and "modernism"'. I am interested in the ways in which this debate relates to ideas raised above: observationalism and romanticism, windows and mirrors. However, I have removed a section on Larkin's influence because it outgrew this article in scope, methodology and length, and have chosen to focus on the completed production rather than the initial, Larkin-based, conception. This is not to downplay Larkin's influence: Plater is an aficionado and wrote the play Sweet Sorrow about the poet.

9. One of Plater's popular Beiderbecke trilogy for ITV (1985-88). Hull also featured briefly in The Beiderbecke Tapes (1987). Plater was an interviewee when the Queen's opening of the Humber Bridge was televised on BBC2 on 17 July 1981. To appreciate the distinction between using a location and integrating it into a production's aesthetics, it is worth considering Hull's other screen appearances. It was used in neither Up ' $n$ 'Under (1998) nor Amazing Grace (2007), despite their subjects, but has featured in the film Clockwise (1986) and, posing as another location, in Agatha Christie's Poirot (ITV, 1989-present). Despite having to compromise on Up ' $n$ 'Under, John Godber shot two BBC dramas in Hull: the pioneering interactive drama Thunder Road (2005) and the Scene children's drama Oddsquad (2005).

10. In his Handbook to Hull and the East Riding of Yorkshire, quoted as a preface to Winifred 


\section{Dave Rolinson}

Holtby's Land of Green Ginger (1955: 8), Sir Albert Kaye Rollit presumes it was 'most probably so called from its having been a place for the manufacture or sale of green ginger, a conserve of ginger and lemon juice, temp. Henry VIII'. Locals have suggested various other interpretations.

11. There are other echoes. For instance, Sally's underlying concern for Mike's longterm safety comes to mind when considering the way the signification of the street shifts in Holtby's novel when Joanna later experiences it during the movement of Teddy's coffin (1955: 272).

12. I deleted subjective recollections because of the formality of academic discourse, but Hull is my home town and I have memories of virtually every location in the play. Like the characters, I was born in the Hessle Road area but moved to North Hull Estate (others in my family were moved to nearby Bransholme). Over the years I have drunk in every pub in the play, but have not yet worked out how to claim this on backdated research expenses.

\section{References}

Unpublished sources

Alan Plater Papers, Brynmor Jones Library, University of Hull: a substantial collection of scripts, correspondence, scrapbooks of reviews, drawings, promotional materials and research materials used by Plater while working on scripts.

BBC WAC: BBC Written Archives material including a Programme-as-Broadcast sheet containing credits, details of stock film, music references and timings.

\section{Published sources}

Anonymous (1974), 'If people think Hull smells of fish it does not matter - playwright', Hull Daily Mail, 26 March.

Anonymous (1975), 'Regions best drama output - says BBC's David Rose', Stage and Television Today, 4 September, p. 14.

Banks-Smith, Nancy (1973), 'Green Ginger', Guardian, 16 January.

Black, Peter (1973), 'Peter Black', Daily Mail, 16 January.

Buckley, Leonard (1973), 'Land of Green Ginger', Times, 16 January, p. 10.

Campbell, Patrick (1972), 'The quiet revolution in BBC drama', Stage and Television Today, 10 February, p. 10.

Chappell, William (1859), Popular Music of the Olden Time. The Whole of the Airs Harmonized by G. A. Macfarren, London: Cramer, Beale, \& Chappell. (Facsimile edition from Elibron Classics, 2005.)

Clayton, Sylvia (1973), 'Romance in a melancholy light', Daily Telegraph, 16 January.

Colbert, Michael (1973), 'In my view ...', Yorkshire Post, 16 January.

Cooke, Lez (2003), British Television Drama: A History, London: British Film Institute.

Cooke, Lez (2005), 'Regional British television drama in the 1960s and 1970s', Journal of Media Practice, 6:3, pp. 145-56.

Cooke, Lez (2007), 'BBC English Regions Drama: Second City Firsts', in Helen Wheatley (ed.), Re-viewing Television History: Critical Issues in Television Historiography, London: I.B. Tauris.

Courtenay, Tom (2000), Dear Tom: Letters from Home, London: Doubleday.

Gill, Alec (1989), Lost Trawlers of Hull: Nine Hundred Losses 1835-1987, Beverley: Hutton Press.

Gill, Alec (2003), Hull's Fishing Heritage: Aspects of Life in the Hessle Road Fishing Community, Barnsley: Wharncliffe Books. 


\section{'The Surprise of a Large Town'}

Hanson, Barry (2000), 'The 1970s: regional variations', in Jonathan Bignell, Stephen Lacey, Madeleine Macmurraugh-Kavanagh (eds), British Television Drama: Past, Present and Future, Basingstoke: Palgrave, pp. 58-63.

Hill, John (1986), Sex, Class and Realism: British Cinema 1956-1963, London: British Film Institute.

Holtby, Winifred (1955 [1927]), The Land of Green Ginger, London: Jonathan Cape.

Hutchinson, Mike (1987), 'Grim and gritty reflections of life's estate', Hampstead and Highgate Express, 28 August, p. 20.

Jackson, Kevin (2004), Humphrey Jennings, London: Picador.

Jacobs, Jane (1961), The Death and Life of Great American Cities, New York: Vintage. (Page references from 1989 edition.)

Johnson, Catherine and Rob Turnock (eds) (2005), ITV Cultures: Independent Television Over Fifty Years, Maidenhead: Open University Press.

Langley, Noel (2005 [1936]), The Land of Green Ginger, London: Faber Children's Books.

Larkin, Philip (2003), Collected Poems, London: Faber.

Lloyd, A.L. (1994), Early Days: The Watersons, sleevenotes, London: Topic Records.

Mason, Sue (2004), 'Confessions of a famous City supporter', The Journal, September, pp. 4-5.

McGrath, John (1981), The Cheviot, the Stag and the Black, Black Oil, London: Eyre Methuen Ltd.

Morrill, John (2001), 'The Stuarts (1603-1688)', in Kenneth O. Morgan (ed.), The Oxford History of Britain, Oxford: Oxford University Press.

Motion, Andrew (1982), Philip Larkin (Contemporary Writers), London: Methuen.

Palmer, Roy ed. (1986), The Oxford Book of Sea Songs, Oxford: Oxford University Press.

Plater, Alan (1973), 'Views', The Listener, 29 November, pp. 732-3.

Plater, Alan (1975), Humberside Theatre 1970-1975: A Birthday Garland, Hull: Humberside Theatre. (Illustrated by Gary Sargeant.)

Plater, Alan (2000), 'The age of innocence', in Jonathan Bignell, Stephen Lacey, Madeleine Macmurraugh-Kavanagh (eds), British Television Drama: Past, Present and Future, Basingstoke: Palgrave, pp. 68-72.

Plater, Alan (2003), 'Learning the facts of life: forty years as a TV dramatist', New Theatre Quarterly, 19:75, pp. 203-13.

Plater, Alan (2005), 'Tom Hadaway' obituary, The Guardian, 11 March.

Plater, Alan (2006), Doggin' Around, London: Northway Publications.

Rolinson, Dave (2005), Alan Clarke, Manchester: Manchester University Press.

Saynor, James (1992), 'Writers' television', Sight and Sound, 2:7, pp. 28-31.

Scott, Walter (1995 [1817]), Rob Roy, London: Penguin.

Suff, David (2003), The Watersons: Mighty River of Sound, CD box-set booklet, London: Topic Records.

Taylor, G.F. (2006), The British New Wave: A Certain Tendency?, Manchester: Manchester University Press.

Thomas, James (1973), 'Make a play on words - not pictures', Evening News, 16 January. Thomas, Yvonne (1973), “I'm not ee-ba-gooming all the time”', Radio Times, 11 January, p. 11.

Vaughan Williams, Ralph and Lloyd, A.L. (1969 [1959]), The Penguin Book of English Folk Songs, London: Penguin Books.

Television documentaries

Images of Yorkshire: Alan Plater (1989), Yorkshire TV interview programme, 24 July. (On Network DVD edition of The Beiderbecke Trilogy.) 


\section{Dave Rolinson}

Alan Plater - Hearing the Music (2005), BBC Four Time Shift documentary, 26 March.

Travelling for a Living (1966), BBC 2, 16 May. (In The Watersons: Mighty River of Song box set.)

Dave Rolinson is Lecturer in Film Studies at the University of Hull. He is the author of Alan Clarke (Manchester University Press, 2005) and has published various articles on British film and television drama. 